\title{
Analysis on the construction of professional ethics of young college teachers in the Network times
}

\author{
Liman Zhao ${ }^{1, \text { a }}$, Xiaoyun Chen ${ }^{1, b}$ \\ ${ }^{1}$ Jiangxi Science \& Technology Normal University, Nanchang, Jiangxi, 330013, China \\ alimzhao@126.com, ${ }^{b} 40905438 @ q q . c o m$
}

Keywords: Network times; University; young teachers; professional ethics; construction; analysis

\begin{abstract}
Due to the advance of the development of Chinese network information era, this is our country's higher education laid the strict conditions, to computer center of media information technology expands increasingly, in the help and support of the media of information technology, the teaching quality of our country also has the further improved. At this stage, a good education for students in the future direction of development has a vital link. And the main factor that affects the enthusiasm and enthusiasm of the students is the teacher. Therefore, in the age of the Internet, strengthen the professional ethics of young college teachers training can not only stimulate students learning enthusiasm, also can enhance the quality of work of teacher's teaching, and to the students for their future development has laid a good foundation.
\end{abstract}

\section{Introduction}

In order to improve the future development of the whole school, we must first establish a highly educated and highly qualified teachers team. Although the main responsibilities of a teacher is to give students mail knowledge, but if teachers with higher professional knowledge and high professional ethics, the students future development has a crucial role. "The teacher said," once wrote: "ancient scholars must have a teacher. The teacher, so preaching by the industry doubts." The main meaning of this sentence is to say: "the teacher is used to impart knowledge, teach their studies, answer doubts of the people." As a result, we can see that the teachers have higher professional ethics, which has a very important significance for the future teaching work. In addition to strengthening the young teachers' professional ethics training, we must also learn to establish a harmonious relationship between teachers and students. Therefore, this article mainly carries on the full analysis to the network age university youth teacher's professional ethics construction.

\section{The significance of strengthening the construction of young teachers' professional ethics in Colleges and Universities}

The professional ethics of teachers mainly involves three aspects, the first one is the teaching quality, the second aspect is the teaching management; the third aspect is the service aspect. The teacher occupation morality, also known as the teachers' moral or ethics ". Mainly refers to the teachers engaged in education, not only to follow the relevant code of conduct, but also have a certain moral quality. In the present social professional ethics, the teacher's professional ethics is not only an important part of it, but also the most important moral requirement of the present teacher career. It fundamentally requires young teachers in the teaching work to to what kind of mode of emotion and attitude to students and build a good relationship between teachers and students, and deal with all kinds of problems, do a good job, and our dedication to the cause of education a certain strength. And for the better development of the cause of the school, the first to establish a highly educated, high-quality teachers team. There is a link between the three aspects of professional ethics and school, the first one is the development direction of the school in the future; the second aspect is the social service; the third aspect is the training of talents. And young teachers as the educational undertaking of our country in the future hope, and to enhance the professional ethics of young teachers in Colleges and universities can not only enhance the overall quality of teaching in Colleges and universities, but 
also to promote the better development of education in our country. Therefore, strengthening the construction of professional ethics of young teachers in our country is the most important problem to be solved in the teaching of higher education in our country.

\section{The present situation of young teachers' professional ethics in Colleges and Universities}

\subsection{Sense of professionalism}

With the development of the socialist market economy, the speed of development is accelerating. Based on this environment, people begin to pay more and more attention to their quality of life and the pursuit of material. And because most of the young teachers are just leaving school directly into the teaching career, and young teacher's age is still small, has been in a state of prosperity growth, did not experience the difficulties and setbacks. Therefore, in this case, most of the young teachers in their professional responsibilities no deeper understanding, treat their work has been in a perfunctory phenomenon, a serious lack of team consciousness and the spirit that respect property, leading to weakening dedication consciousness phenomenon exists in most of the young teachers.

3.2 Only teaching, not educating people

According to the present teaching situation, the problems of young teachers in our country are not in depth. They only pay attention to their own professional tasks, but they do not pay much attention to the students' Ideological Education and moral education. In addition to a short period of contact with students in class, in their spare time, they rarely communicate with students. They pay little attention to the students' understanding of the knowledge, the students' emotions, the students' learning efficiency and the students' learning style. They only care about their own teaching tasks are completed, whether their knowledge level has been further promoted, which led to the majority of young teachers there are only teaching, not the phenomenon of educating people.

3.3 Did not establish a sound management system

The establishment of a sound management system is closely related to the development of the school in the future. Sound management system, not only to mobilize the enthusiasm of the work of young teachers, but also to improve the professional ethics of young teachers. Therefore, in the formulation of the school management system, according to the actual situation of young teachers to develop. If the application of traditional school management mode to young teachers management, not only can not achieve the desired effect, can also affect the enthusiasm of young teachers work.

\section{Strengthening the construction of young teachers' professional ethics in Colleges and Universities}

4.1 Take education as the guide

With the change of the times, the traditional teaching idea has been to keep up with the pace of the times. Therefore, in order to improve the quality of teaching in Colleges and universities, we must first strengthen the cultivation of young teachers' professional ethics. In the cultivation of young teachers' professional ethics, we must first strengthen the cultivation of young teachers' Ideological education. Cultivation of young teachers' patriotism and collective consciousness. And then to enhance the ideological consciousness of young teachers, to establish a correct sense of work and values of life. Secondly, we should strengthen the cultivation of young teachers' modern teaching methods and national conditions. Let young teachers in a timely manner to understand the development trend of teaching and teaching needs, and to enhance the sense of responsibility and mission of young teachers. Finally, for young teachers were professional ethics education, teach young teachers to establish a clear career goals, and according to the goal to perform. It can not only stimulate the enthusiasm of young teachers, also can put forward to its own higher standard, and threw himself into their education to.

4.2 To standardize the teaching behavior, the direction of policy guidance

The construction of professional ethics of young teachers is a very complicated process, which is not only influenced by the social and economic, but also has a direct relationship with people's own 
values. Therefore, in order to establish a scientific and reasonable construction of professional ethics system, first of all to of young teachers professional ethics norms, let the young teachers clearly understand their true responsibilities and obligations, and to regulate their own behavior and way of teaching. , to establish a series of scientific and reasonable supervision system, for their own good place to timely recognition and encouragement; for their own problems, to timely punishment and criticism, and the problem was corrected promptly, and then to the young teachers' professional ethics construction guidelines to the correct direction of development to. Finally, in order to strengthen the cultivation of young teachers' professional ethics, the leading departments of all colleges and universities should cooperate with each of the secret. And then the young teachers' professional ethics construction will lead to the correct track.

4.3 Establishing scientific reward distribution incentive mechanism

In order to strengthen the construction of young teachers' professional ethics, we should establish a scientific reward distribution and incentive mechanism. In order to improve the school management, we must first improve the education management. In the process of school management to establish a correct concept of fairness and to the teachers and students to create a good working and learning atmosphere. This will not only enhance the teacher's work enthusiasm, but also quite high students learning enthusiasm. In order to make fair theory applied to the management of the school, first of all, it should be linked to the performance award, and fair incentives to teachers. But in order to really do this, we must make a fair and reasonable arrangements for the various issues of teachers. For example, the teacher's housing allocation problem, the problem of salary and bonus, the work of the teacher appraisal, the promotion of teachers and so on, to uphold the principle of openness, fairness and impartiality. Try to avoid the phenomenon of unfair, so as to avoid the teacher's work enthusiasm, and thus lead to the overall decline in the quality of teaching.

\section{Summary}

Through the elaboration of this paper, we make a more in-depth understanding of the importance of professional ethics of young college teachers in the network era. Strengthening the cultivation of young teachers' professional ethics can not only improve the overall quality of college education, but also promote the development of education in our country. Therefore, in order to strengthen the construction of young teachers' professional ethics, we should start from three aspects, the first aspect is to educate young teachers to education as the guide. The second aspect is to educate young teachers in order to regulate the guide line and policy guidance; the third aspect is to establish a scientific reward distribution incentive mechanism. Only truly doing these three points, in order to improve the professional ethics of young teachers in Colleges and universities. Through the elaboration of this article, we can give some suggestions to the young teachers' professional ethics construction in our country.

This paper is the research and practice of teaching quality evaluation system of College Teachers' education and teaching reform in Colleges and Universities: a case study of Jiangxi Science \& Technology Normal University as an example. The Topic number of the research: JXJG-15-10-20

\section{References}

[1] Chen Runyang, Li Yong. On the construction of university young teachers ethics [J]. China forestry education, 2011,02:15-19.

[2] Song Xiufang. Analysis of the big data era of young college teachers' occupation moral status of [J]. theory, 2015,27:114-115.

[3] Chang Liang, Li Chengen. Research on the cooperative development mode of the "moral education" ability of young teachers in Universities -- Based on the "super professional" perspective of university teachers [J]. modern education management, 2015,09:72-77. 
[4] $\mathrm{Xu}$ Zhenhua. Reflections on strengthening the construction of professional ethics of young teachers in Colleges and universities in the new era [J]. Contemporary Education Forum (Management Edition), 2010,01:86-88.

Wu Hai Shang [5]. Young college teachers' professional value view of research -- Based on the questionnaire investigation of five universities in Guangxi [J]. China Adult Education and 2010,12:115-116.

[6] Yu Fang, $\mathrm{Xu}$ Yumei. Investigation and analysis of the current situation of young teachers' professional ethics in Colleges and Universities under the new situation -- Taking Weifang city of Shandong Province as an example 2014,03:105-108. Journal of the Party School of municipal Party committee of Leshan, [J]. 